\title{
Se terminaron las recetas
}

José Mauricio Loucel

Rector de la Universidad Tecnológica de El Salvador/ UTEC

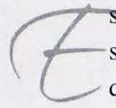
$s$-indudable que el mundo se encuentra en una crisis que seguramente afecta $o$ afectará, tarde o temprano, a todos los pueblos de la Tierra. No podemos prever lo que vendrá a continuación, pero indudablemente todo es el producto de un sistema que se ha contradicho permanentemente en provecho de políticas excluyentes e injustas.

Durante muchos años estuvimos sujetos a los consejos que los organismos internacionales nos propusieron e impusieron, con el beneplácito de aquellos para quienes era ventajoso aceptarlos e implantarlos, no importando si los mismos habían sido sujetos a un análisis exhaustivo.

No estamos capacitados para afirmar que la crisis financiera golpeará severamente nuestra economía; pero, en todo caso, esta llega cuando en El Salvador la pobreza se ha incrementado y los procesos electorales desatan pasiones e inercias.

Nos dijeron que el proceso de rebalse solucionaría los problemas socia- les y que era necesario debilitar el Estado privatizando sus empresas, $y$, casualmente en nuestro caso, por medio de procedimientos dudosos y corruptos.

Ahora el Estado casi no tiene nada, salvo los problemas que significan un alto endeudamiento, una falta de liquidez, una delincuencia que abate a toda la población, un desempleo creciente, una dependencia de las remesas y un transporte público caótico y abusivo que ha penetrado las entrañas corruptas de una entidad que hemos votado, pero no elegido.

Desde luego, hemos cuidado la macroestabilidad; pero no hemos aumentado el empleo, hemos seguido puntualmente las recetas que nos endilgaron precisamente aquellos que no la practicaban en su patio; pero no hemos podido resolver el problema de la pobreza.

Se acerca un nuevo gobierno, que deberá definir posiciones importantes para nuestro futuro. Marcar el rumbo del mismo no es nuestra función; sin embargo, queremos
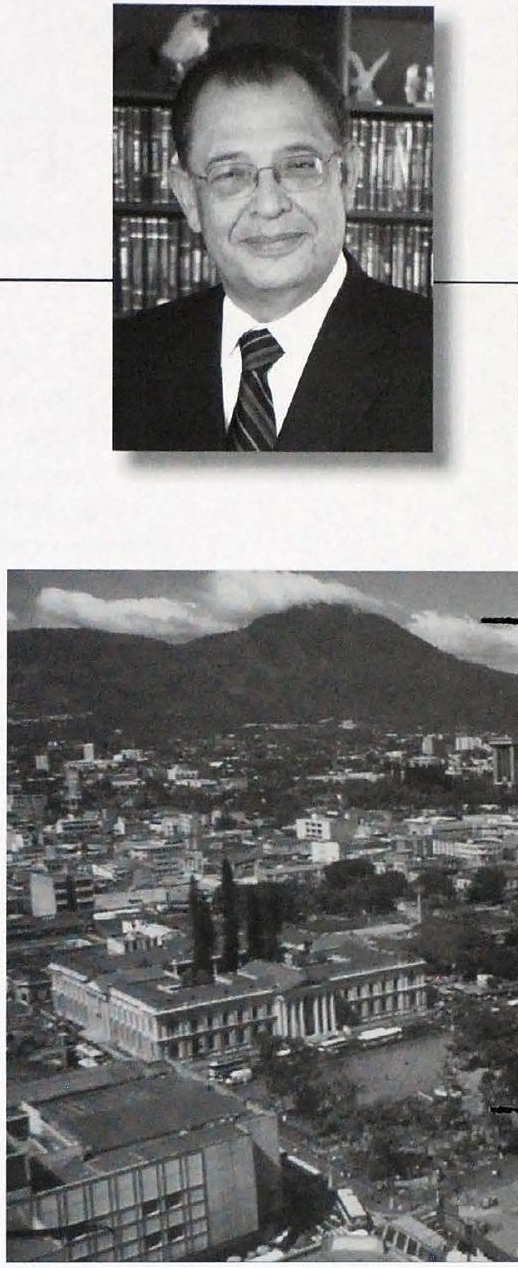

"Desde luego, hemos cuidado la macroestabilidad; pero no hemos aumentado el empleo, hemos seguido puntualmente las recetas que nos endilgaron..." 
pensar que ese rumbo no estará encasillado en dogmas inaplicables en nuestra propia realidad e identidad. La polarización política, negativa en sí misma, no debe descansar necesariamente en postulados absolutistas que consideran inapelables sus postulados históricos. Tampoco se debe aferrar al egoísmo cínico e individualista que privilegia el mercado y las utilidades sobre el bien de un sufrido pueblo que está clamando por una paz auténtica y un bienestar meridiano.

Y esto solo es posible en la medida en que renunciemos al "yo exclusivamente tengo la razón, los demás son traidores, dementes, o bandoleros". El aferrarse a un encuadramiento mental solo refleja egocentrismo y falta de flexibilidad.

Los mismos tiempos nos orillan a eso. $\mathrm{O}$ hacemos pactos que nos hagan caminar hacia una patria mejorada, o nos hundimos en el conflicto y el caos.

Como puede entenderse, no estoy descalificando a ninguna organi- zación política, ni a ningún candidato. Si espero que el próximo presidente tenga la absoluta independencia de decisión para no ceder ante ningún tipo de influencia ni presión; que tenga el valor y el coraje para defender los intereses de todos los salvadoreños sin amilanarse ni claudicar.

Deseo que sea un presidente lo suficientemente humilde como para dejarse rodear de sinceros colaboradores que tengan el valor de decirle si algo no está bien hecho.

Un presidente que no se deje adular por interesados que mendigan favores a costa del prestigio presidencial. Un presidente que actúe por sí mismo, con absoluta conciencia de que su máximo deber es defender la democracia y no solo la Constitución.

Deseo un presidente que crea en Dios fervientemente, y le pida, como Salomón, sabiduría suficiente para gobernar a su pueblo.

(Artículo publicado originalmente en La Prensa Gráfica.) 